UDC 621.039.53

O. Rudenko,

V. Voyevodin, DSc, Prof.,

S. Gozhenko, $\mathrm{PhD}$,

P. Mischenko

Institute of Solid State Physics Materials and Technologies, National Science Center "Kharkov Institute of Physics and Technology" of the National Academy of Sciences of Ukraine, 1 Academic Str., Kharkov, Ukraine, 61108; e-mail: rudenko@kipt.kharkov.ua

\title{
CONDUCTING LOCAL CUTOUT FROM THE SURFACE OF THE VVER-1000 REACTOR VESSEL
}

О.Г. Руденко, В.М Воєводін, С.В. Гоженко, П.О. Міщенко. Проведення локальних вирізок з поверхні корпусу реактора BBEP-1000. Цілісність корпусу реактора $€$ найважливішим елементом демонстрації працездатності атомної електростанції протягом не менше 80 років. Тривала експлуатація матеріалів при підвищених температурах виявляється у втраті пластичності та помітному зсуві інтервалу переходу від в'язкого руйнування до крихкого в області підвищеної температури. Окрихчення корпусу реактора ВВЕР пов'язано з багатьма факторами які відбуваються в результаті тривалої експлуатації. Радіаційне окрихчення є ключовим фактором, який визначає термін служби будь-якого реактора типу ВВЕР. 3 огляду на те, що ВВЕР були призначені для роботи протягом 40 років, існують проблеми, які необхідно вирішити, щоб зменшити невизначеність у застосуванні нормативних вимог. Існуючі підходи в атомній енергетиці України до оцінки в'язкості руйнування опромінених матеріалів корпусу реактора грунтуються на емпіричних кореляціях між параметрами тріщиностійкості та ударної в'язкості, що призводить до переоцінки терміну безпечної експлуатації корпусів реакторів. Для продовження терміну служби реакторів ВВЕР необхідні точні прогнози підвищення температури в'язкокрихкого переходу $\left(\Delta T_{K}\right)$ для сталі корпусу реактора під дією нейтронного випромінювання, які знаходяться за межами існуючої бази даних. Наприклад, доза нейтронів в RPV буде, принаймні, подвоєна. 3 цим фактором пов'язані невизначеності щодо ефектів флаксу, ефектів щодо високого вмісту нікелю, невизначеності щодо застосування механіки руйнування і термічного відпалу. В даній роботі пропонується провести дослідження металу на в'язкість руйнування, безпосередньо отриманого 3 корпусу реактора, щоб вивчити прогноз $\Delta T_{K}$ від терміну роботи, опромінення, температури і кількості циклів пуск/зупинка при випробуванні зразків меншого розміру. На сьогоднішній день експериментальні методи механіки руйнування дозволяють прямо визначати властивості матеріалів за допомогою випробувань малорозмірних зразків, що дає можливість визначитись 3 терміном експлуатації корпусу реактора. В ННЦ ХФТІ розроблено обладнання, методика та має досвід роботи, який дозволяє отримати додаткову інформацію при аналізі стану металу обладнання що тривалий час знаходиться в експлуатації.

Ключові слова: корпус реактора, зразки-свідки, радіаційне окрихчення, температура крихкості, дозова залежність

O. Rudenko, V. Voyevodin, S. Gozhenko, P. Mischenko. Conducting local cutout from the surface of the VVER-1000 reactor vessel. Integrity of the reactor pressure vessel is a critical element in demonstrating the capability of nuclear power plant for operation to at least 80 years. Long-term exploitation of materials at elevated temperatures is manifested in a loss of ductility and a marked shift in the interval from ductile fracture to brittle transition to higher temperatures. Embrittlement of the VVER reactor vessel is associated with many factors that result from prolonged operation. Radiation embrittlement is a key factor that determines the operational long-term of any reactor pressure vessel (RPV). Given that VVERs were intended to operate for 40 years, there are issues that need to be addressed to reduce the uncertainties in regulatory application. Existing approaches in the nuclear power industry of Ukraine to assess the fracture toughness of the irradiated materials of pressure vessel are based on empirical correlations between the parameters of crack resistance and impact strength which leads to a reassessment of the long-term safe operation of RPV. VVER reactors long-term operation require accurate predictions increases in the ductile-brittle transition temperature $\left(\Delta T_{K}\right)$ of reactor pressure vessel steels of neutron irradiation-induced that are outside the existing database. For example, the neutron dose in RPV will be at least doubled. Associated with this factor are uncertainties regarding flux effects, effects of relatively high nickel content, uncertainties regarding application of fracture mechanics and thermal annealing. In this paper, it is proposed to conduct a research of the metal on fracture toughness, directly obtained from the reactor pressure vessel, in order to study the $\Delta T_{K}$ prediction on operating time, irradiation, temperature and number of start/stop cycles when testing sub-sized specimens. To date experimental methods of fracture mechanics allow the directly to determine the properties of materials through the testing of sub-size specimens, which allows to determine long-term of RPV. In NSC KIPT have been developed the equipment, methodology and experience, which allows obtaining additional information in the analysis of the state metal of the equipment, which has been in long-term operation.

Keywords: reactor vessel, surveillance-specimens, radiation embrittlement, brittleness critical temperature, dose dependence

Introduction. The radiation resource of the reactor vessel (RPV) largely determines the operational life of the nuclear power plant (NPP) installation. Prolonged operation of materials at elevated

DOI: 10.15276/opu.1.57.2019.07

(c) 2019 The Authors. This is an open access article under the CC BY license (http://creativecommons.org/licenses/by/4.0/). 
temperatures is manifested in a noticeable loss of ductility and shear transition interval from ductile to brittle fracture in a high temperature region. This shift increases the probability of failure of the vessel under normal operating conditions, and especially in emergency cooling, thermal shock and hydro test. Therefore, for analysis of the operability RPV and scientific basis for extending the lifetime of the entire nuclear power plant it becomes necessary to adequately predict changes in the mechanical properties of RPV steel on a long-term operating period of 60 years or more. This, in turn, requires an understanding of the degradation mechanisms have become the RPV steel under the influence of operational factors: the working temperature and irradiation.

For a complete understanding of the processes taking place in the RPV steel is required to obtain timely information on the degradation properties of the RPV steel, taking into account an increased service life-time. One of the most important sources of information on changing the properties of the metal of the reactor vessel under the influence of neutron radiation and temperature is the program of surveillance-specimen. The program also takes into account the influence of various alloying and impurity elements on embrittlement of the reactor pressure vessel steel as a result of long-term operation.

At present, there are three ways of obtaining information about the irradiated materials of the reactor pressure vessel: Accelerated irradiation to high values of fluence of fast neutrons in research reactors for a time that exceeds the design lifetime of the reactor vessel. This allows the use of different type's specimens to determine the complex of mechanical properties, as well as the study of the phase-structural state of materials; 2. Irradiation of standard surveillance-specimens (SS) directly in reactors of nuclear power plants; 3. Investigation of the steels of the RPV taken out of operation by cutting out the templates.

The study of SS according to PNAE G-7-002-86 (PNAE) allows to evaluate the state of the RPV metal and to decide on its further operation. The main process that limits the lifetime of RPV NPP is the reduction of ductility as a result of neutron irradiation in combination with high temperature operation. The basic process that limits the lifetime of buildings of nuclear power reactors is to reduce the plasticity as a result of neutron irradiation in combination with high temperature operation. The result is a shift of the critical temperature brittleness steel $\left(T_{K}\right)$ in the region of higher temperatures, which increases the probability of brittle failure of the RPV in during operation.

According PNAE total shift of the critical temperature brittleness $\left(T_{K}\right)$ is defined as the sum of shifts critical temperature brittleness unirradiated and irradiated surveillance-specimens:

$$
\Delta T_{K}=T_{k 0}+\Delta T_{F}+\Delta T_{\mathrm{FLAX}}+\Delta T_{T}+\Delta T_{N},
$$

where $T_{K 0}$ is the critical temperature brittleness of the origin material; $\Delta T_{F}$ - shift of the critical temperature brittleness as a result of the SS irradiation; $\Delta T_{\mathrm{FLAX}}-$ shift in the critical temperature brittleness due to the accumulation of radiation-induced precipitates as a result of irradiation with different density of fast neutron flux; $\Delta T_{T}$ - shift of the critical temperature brittleness as a result of segregation processes at operating temperatures over a long time of operation; $\Delta T_{N}$ - shift of the critical temperature brittleness as a result from of the cycles load during the operation period.

According to PNAE, if the fluence is in the range $10^{22} \leq F n \leq 3 \cdot 10^{24} \mathrm{n} / \mathrm{m}^{2}$, then the values of $\Delta T_{F}$ are determined by the formula:

$$
\Delta T_{F}=A_{F} \cdot\left(F n / F_{0}\right)^{1 / 3},
$$

where $A_{F}$ is the coefficient of radiative embrittlement, ${ }^{\circ} \mathrm{C}$, taken according to PNAE data; $F n$ is the fluence of neutrons with $E \geq 0.5 \mathrm{MeV}, \mathrm{n} / \mathrm{m}^{2}$, for 60 years of operation, the RPV can acquire fluence to (5.5...6.0) $\cdot 10^{23} \mathrm{n} / \mathrm{m}^{2} ; F_{0}=10^{22} \mathrm{n} / \mathrm{m}^{2}$.

Testing the accelerated-irradiated SS for impact testing determines the shift of the critical temperature brittleness due to the irradiation of $\Delta T_{F}$, to which the shift of the critical temperature brittleness due to the $\Delta T_{\text {FLAKS }}$ flag is added. For example, if the concentration of nickel in the steel RPV exceeds $1.5 \mathrm{wt} \%$, which is relevant for VVER Ukraine, according to experimental data $\Delta T_{\text {FLAKS }}=0.25 \Delta T_{F}[1,2]$.

According to PNAE, the contribution of $\Delta T_{T}$ to the total $\Delta T_{K}$ shift is 0 at a temperature of up to $350^{\circ} \mathrm{C}$ for the all period of regulatory use. However, for equipment in excess of the design operation, it 
is necessary to take into account the contribution of $\Delta T_{T}$ to the total shift of the critical temperature brittleness due to the segregation of phosphorus on the interface, which can be up to $20^{\circ} \mathrm{C}[3-8]$.

Thus, it is possible to estimate the value of the total shift of the critical temperature brittleness $\left(\Delta T_{K}\right)$ for the long-term operating of the reactor on $\approx 60$ years. According to PNAE, the total shift of the critical temperature brittleness $T_{K}$ can be written as $\Delta T_{K}=1.25 \Delta T_{F}+20^{\circ} \mathrm{C}$ and according to this value it is already possible to estimate the state of RPV NPP.

Analysis of recent publications and problem statement. The main advantage of the program SS in VVER-1000 in comparison with the VVER-440, this is not a high rate of advance of fluence. As a result, a place was chosen in which the flux density of fast neutrons is no more than 4 times higher than this value at the wall of the RPV.

The main disadvantages of the surveillance-specimens program of VVER-1000 are:

- Installation of surveillance-specimens in places with a large gradient of fast neutron flux density along the height and azimuth of the container. As a result, SS irradiated in one container may differ in several times in neutron fluence, which does not allow collecting groups of uniformly irradiated specimens for mechanical tests.

- Failed place for cutout SS from the base metal (different region of thermal influence). In the issue, the variation of experimental data SS did not allow us to adequately estimate the aging temperature based on standard sets, which led to an extremely conservative estimate of the radiation embrittlement of the base metal(BM) VVER-1000 RPV.

As a result, in order to obtain representative data in determining the critical temperature brittleness, it was necessary to increase the number of specimens in the impact tests. Based on this, a methodology for reconstitution SS VVER-1000 was developed, which made it possible to obtain a representative database. All applicable regulations have been developed based on these results. In new NPP projects, correction places for cutout SS from of the RPV shell and installation sites for more uniform irradiation have been selected.

However, it is possible to improve of the SS program, but it will still present only a probabilistic analysis of the state of the RPV metal as the comparison between the change in the state of the SS and of the RPV metal is not entirely correct. Such an approach characterizes the properties of the metal under different conditions of stress-strain state and loading rates. For example, when testing SS for impact test, a change in the stress-strain state is observed at the tip of the Charpy specimen notch, in the RPV steel the stress-strain state occurs in the vicinity of the crack formed in the RPV under loading and temperature.

Calculated in accordance with the PNAE rules, the predicted changes in the $T_{K}$ steel of the RPV VVER from the radiation dose can be approximated by the power function. However, the shift $T_{K}$ under irradiation depends on a greater number of factors: from neutron fluency, the chemical composition of the steel and the characteristics of the irradiation conditions.

Radiation-induced defects lead to embrittlement of the material by two mechanisms: hardening and non-hardening [3].The content of the strengthening mechanism is that irradiation by fast neutrons leads to the appearance of radiation-induced elements: radiation defects-dislocation loops and precipitates enriched in $\mathrm{Ni}, \mathrm{Mn}$, and $\mathrm{Si}$. In this case, the role of the smallest clusters formed of $\mathrm{Fe}, \mathrm{Ni}$, and $\mathrm{Mn}$ atoms is reduced to a hardening effect [ $4-8]$. The results present in Fig. 1 [5] show that an increase in the $\mathrm{Ni}$

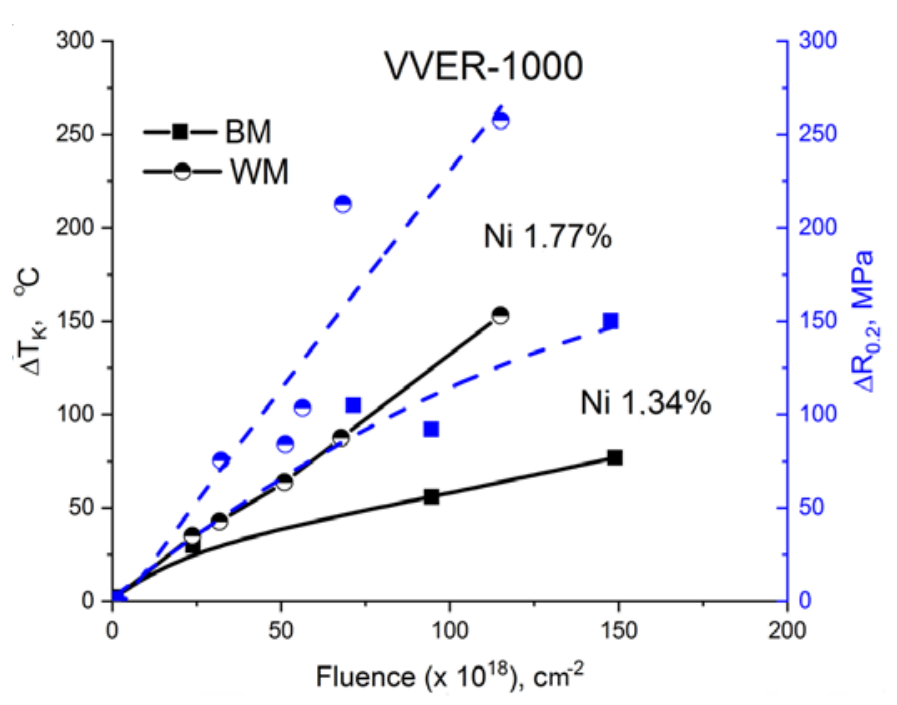

Fig.1. Dependence of the critical temperature of brittleness and yield stress on the neutron fluence for VVER-1000 RPV steels with different nickel content 
content from 1.34 to $1.77 \%$ leads to a significant increase in $\Delta T_{K}$ with an increase in the irradiation dose. It should be remembered that $\mathrm{Ni}$ contributes to the segregation of phosphorus on the interface, which in turn can lead to a significant decrease in the critical temperature of brittleness. In Ukraine, VVER-1000 reactors steels are quite clean in terms of phosphorus and copper, but they have increased nickel content.

According to PNAE, the critical temperature of brittleness of RPV steel is $\Delta T_{T}=0{ }^{\circ} \mathrm{C}$ for the whole period of operation at working temperature. Microstructural studies of temperature surveillancespecimens did not confirm the assumption that the hardening mechanism significantly influences the change in the critical temperature of brittleness as a function of the holding time up to 140000 hours at a temperature of $\sim 310 \ldots 320^{\circ} \mathrm{C}$. The density of precipitates of carbide and carbonitride phases in the investigated of weld metal (WM) surveillance-specimens practically does not change and, consequently, cannot have a significant effect on the change in strength characteristics. Allocations of any other phases in $\alpha$-iron, other than carbide and carbonitride, were not found in the studies. Analysis of the microhardness of the SS after various isothermal exposures showed that the values of microhardness remained practically unchanged. Consequently, there should be no change in the state of bainite. However, the results of tests of the SS WM showed that in the specimens with $\mathrm{Ni}<1.3 \%$ the values $\Delta T_{T}$ are up to $20^{\circ} \mathrm{C}$, and with the content $\mathrm{Ni}>1.3 \%$ - increase to $40^{\circ} \mathrm{C}$. At the same time, as the fluence increases, the share of brittle intergranular fracture can reach up to $25 \%$, while the grain-boundary concentration of phosphorus grows with increasing nickel content in steel [5 - 9].

Thus, under conditions of prolonged operation at working temperatures, the contribution of a non-hardening mechanism becomes especially important for the VVER-1000 reactor and can become decisive when extending the service life of the reactor to 60 years or more. Consequently, alloying elements and especially impurities must be taken into account when analyzing the dependence $\Delta T_{K}=f$ (fluence).

The results of tests of irradiated surveillance-specimens can be used to assess the technical state of the RPV only if the conditions for irradiating of the SS and the RPV are known [10]. Fig. 2 [11] show the relative integral neutron flux/fluence for $E>0.5 \mathrm{MeV}, 1 \mathrm{MeV}$, displacements per atom(DPA) through the vessel of VVER-1000 type of reactors and the values of the approximation according to Regulatory Guide ASTM-E900-02. The attenuation of the neutron fluence for the PWR reactors occurs according to the law $F(x)=F_{0} \exp (k x)$, where $F_{0}$ is the density of the flow on the inner surface $\left(10^{23} \mathrm{n} / \mathrm{m}^{2}\right.$; $E>1 \mathrm{MeV}$ ), the coefficient attenuation $k \approx 0.24, x$ - thickness walls of RPV. The attenuation of the fluence with $E>0.5 \mathrm{MeV}$ for VVER reactors occurs more slowly than the attenuation of the neutron fluence with $E>1 \mathrm{MeV}$. This means that the values of the fluence neutrons with $E>0.5 \mathrm{MeV}$ are more conservative than the value of $\mathrm{k}$ in ASTM-E900-02. Thus, the ASTM-E900-02 standard, which uses DPA to weaken the neutron flux in the thickness of a RPV PWR, cannot be directly applied to the Russian formula for the estimation temperature shift $\Delta T_{K}$.

Despite this, a change in the neutron flux density along the thickness of the VVER-440 wall is described quite well in work [12] and can be approximated by a power function. At the same time, the coefficient of attenuation $k$ for the fluence and neutron flux density with $E n>0.5 \mathrm{MeV}$ is equal to $0.09 \mathrm{~cm}^{-1}$, and for the DPA $-0.11 \mathrm{~cm}^{-1}$, respectively. Analogously, the neutron flux density distributions on the inner surface and the thickness of the RPV VVER-1000 were analyzed [13]. The neutron fluence with $E n>0.5 \mathrm{MeV}$ over the metal thickness varied from $(5 \ldots 6) \cdot 10^{23} \mathrm{n} / \mathrm{m}^{2}$ on the inner wall to $\sim 0.5 \cdot 10^{23} \mathrm{n} / \mathrm{m}^{2}$ on the surface

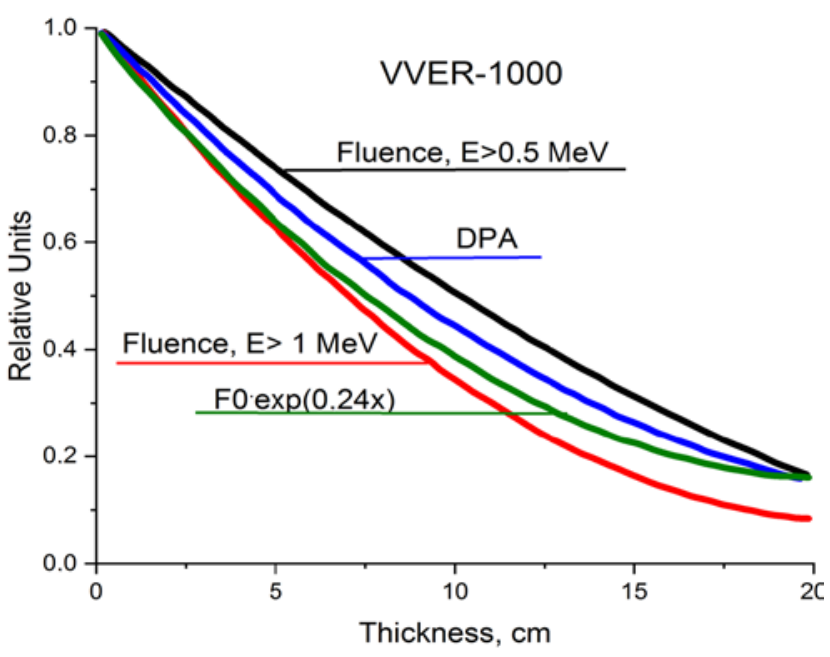

Fig. 2. Attenuation of neutron fluence in the thickness of the VVER-1000 RPV [14] 
RPV. The density of the neutron flux decreases by more than 10 times, with the neutron energy spectrum changing. For example, neutrons with energies up to $5 \mathrm{MeV}$ are completely weakened already at a thickness of $6.5 \mathrm{~cm}$. The ratio of the rates of radiation damage, thermal and radiation annealing also varies. Having carried out a literary analysis of the change in the neutron flux density along the thickness of the RPV VVER-1000 and taking into account that the neutron flux density weakens in accordance with the power law $F(x)=\mathrm{F}_{0} \cdot e^{k x}$, the coefficient of attenuation along the RPV thickness $k=(0.08 \ldots 0.12)$. Thus, based on the results of computational studies at a known flux density of neutrons with energy $E>0.5 \mathrm{MeV}$, neutron fluence along the wall thickness of the reactor shell can be estimated, which allows comparing the "dose" obtained on the surveillance-specimens and specimens cutting from the outer surface of the RPV. In this case, the attenuation of radiation damage along the thickness of the RPV also depends on the initial state of the metal. The analysis carried out made it possible to estimate the $\Delta T_{K}$ shift with respect to the outer and inner walls of the shell and can reach up to $\approx 25{ }^{\circ} \mathrm{C}[14]$.

Purpose. It is quite difficult to predict the degree of the radiation embrittlement RPV steel under long-term operation and it is not always possible to obtain an unambiguous answer. Non-destructive methods of monitoring the evaluation resistance to brittle fracture of the RPV VVER are not in use, and traditional ones are not applicable.

In the NSC KIPT for monitoring the state of the metal after a long-term of operation, a methodology was developed and appropriate equipment for remote cutout of the small-sized templates from the surface of equipment that was in operation for a long time. The developed equipment makes it possible to perform electro-erosive cutout of templates without reducing the performance characteristics of products. This equipment was approved for control of the base metal of main circulating pipelines a number NPP in Ukraine after long time exploitation, Table 1 . As a result, the control of the chemical composition, the structure of the metal, and the tests of mechanical properties were performed. An analysis was made of the accumulation of hydrogen under long-term operating conditions and working temperatures.

Table 1

Thickness of cut templates from main circulating pipelines

\begin{tabular}{|c|c|c|c|c|c|}
\hline $\begin{array}{l}\text { The place for cutting } \\
\text { samples from main } \\
\text { circulating pipelines }\end{array}$ & $\begin{array}{l}\text { Operation } \\
\text { time, } \\
\text { (thousands } \\
\text { of hours) }\end{array}$ & $\begin{array}{l}\text { Wall } \\
\text { thickness } \\
\text { (mm) }\end{array}$ & $\begin{array}{l}\text { Wall } \\
\text { thickness, } \\
\text { (min. allow- } \\
\text { ?ble) (mm) }\end{array}$ & $\begin{array}{l}\text { Thickness of } \\
\text { template, } \\
\text { (mm) }\end{array}$ & $\begin{array}{l}\text { Wall thickness after } \\
\text { cutout template } \\
\text { (with the surface } \\
\text { grinding), (mm) }\end{array}$ \\
\hline $\begin{array}{l}\text { Rovno NPP, } \\
\text { unit № } 1\end{array}$ & $\approx 100$ & 43 & 34 & 4.7 & 36.8 \\
\hline $\begin{array}{c}\text { Rovno NPP, } \\
\text { unit № } 2 \\
\end{array}$ & $\approx 100$ & 38.3 & 34 & 1.6 & 36.1 \\
\hline $\begin{array}{c}\text { Rovno NPP, } \\
\text { unit № } 3\end{array}$ & $\approx 100$ & 94.8 & 63.1 & 4.2 & 82.2 \\
\hline $\begin{array}{c}\text { South-Ukraine NPP, } \\
\text { unit № } 1\end{array}$ & $\approx 100$ & 87 & 63.1 & 3.5 & 81 \\
\hline $\begin{array}{c}\text { South-Ukraine NPP, } \\
\text { unit № } 2\end{array}$ & $\approx 100$ & 86.5 & 63.1 & 4.0 & 82.2 \\
\hline $\begin{array}{c}\text { South-Ukraine NPP, } \\
\text { unit № } 3\end{array}$ & $\approx 100$ & 87.2 & 63.1 & 3.2 & 82.1 \\
\hline $\begin{array}{c}\text { Zaporozheye NPP, } \\
\text { unit № } 1\end{array}$ & $\approx 100$ & 83.1 & 59 & 4.4 & 79.1 \\
\hline $\begin{array}{c}\text { South-Ukraine NPP, } \\
\text { unit № } 1\end{array}$ & $\approx 200$ & 87 & 63.1 & 3.0 & 81.0 \\
\hline $\begin{array}{c}\text { South-Ukraine NPP, } \\
\text { unit № } 2\end{array}$ & $\approx 200$ & 86.5 & 63.1 & 3.5 & 81.4 \\
\hline
\end{tabular}


Methodology of experiment. The procedure for cutout of the templates from the surface RPV VVER-1000. Using data from ultrasonic monitoring of the reactor vessel, it is possible to detect places where cutout metal SSs up to $3 \mathrm{~mm}$ thick will not lead to a decrease in the performance of the RPV. Experience of research the base metal of the main circulating pipelines a number of Ukrainian NPPs showed that the cutout metal is sufficient for conducting a research, including testing by destructive methods.

Cutout of the template from the reactor vessel takes place by analogy with the remote cutout of small-sized templates with a main circulating pipeline. Equipment was debugged in laboratory conditions at the stands of the NSCKIPT and S-UNPP, where the work of the cutout unit on the manipulator SK-187 figured was simulated, Figs. 3 and 4.

Equipment for cutout templates is presented in the form of two functional modules. First module is located on the reactor wall under conditions of high radiation level. The second module operates under the conditions of a radiation background acceptable for maintenance personnel. A brass wire electrode with a diameter of $0.2 \mathrm{~mm}$ will be used to cutout the template from the RPV. The thickness of the cutting in this case is $\approx 0.3 \mathrm{~mm}$, and the average cutting speed is about $\sim 3 \mathrm{~mm} / \mathrm{h}$. Through the control unit, the whole process of cutout the template is monitored. All the work of the electro-erosive cutout is controlled remotely via a 50 -meter flexible cable.

To illustrate the possibilities of the method, Fig. 4 shows the location of the module of electro erosion cutout with a rigid plate electrode in relation to the simulator of the RPV at the SUNPP stand. The geometric dimensions and location of the RPV simulator are fully consistent with real values. The equipment is delivered to the place of cutout of the templates by the manipulator SK-187. Using rigid electrodes allows you to arrange templates cutout in one step. For example, in conditions of a high level of radiation exposure, a single stage can be of decisive importance.

At the final stage of the cutout process, the template is tearing off from the surface of the RPV simulator together with the equipment for cutout. On the surface of the vessel imitator was formed a seam, which is subsequently delete. Sometimes cutout should be done with sparing regime to avoid a temperature rise in the template (not lead to structural and phase transformations in the metal). In this case, it is necessary to take into account that the overall speed of the cutout of the template decreases.

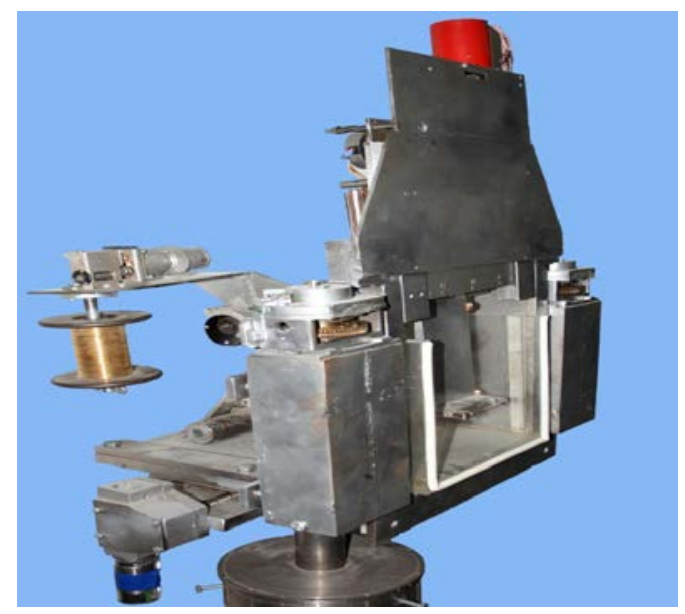

Fig. 3. Module for cutout templates

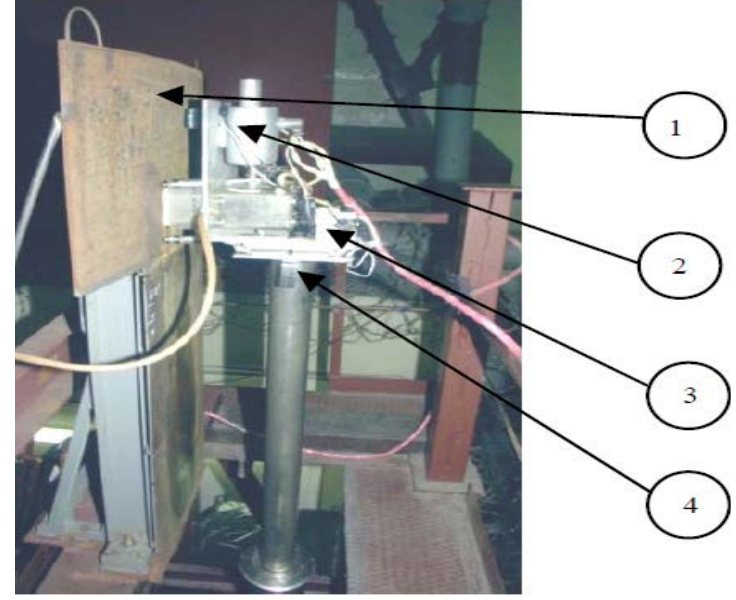

Fig. 4. The arrangement of the cutout equipment relative to the simulator at the stand of the SUNPP: 1 - the simulator RPV, 2 - the unit of the electro-erosive cutout, 3 - the mounting platform, 4 - the rod SK-187

Results of the research. Method "Determining the temperature of ductile-brittle transition of sub-sized specimens with using the acoustic emission". In some cases, to extend the long time operation of equipment it is impossible to conduct traditional tests of standard specimens, but it is necessary to assess the state of the metal equipment that has been in use for a long time. The NSC KIPT 
developed a method and equipment that allows the analysis of the condition of metal equipment to use sub-sized specimens instead of standard specimens.

The method is based on the determination of the temperature ductile-brittle transition of the individual elements of the specimen, which is made from a template directly cut from the surface of the equipment. The equipment allows recording of acoustic emission impulses in a wide range of temperatures, which are generated by the destruction of specimen elements. In this case, for the analysis of the metal of the equipment, a monolithic specimen with several destruction zones is used. The shape of the specimens for research and the fixture for determining the temperature ductile-brittle transition are presented in Figs. 5 and 6 [15].

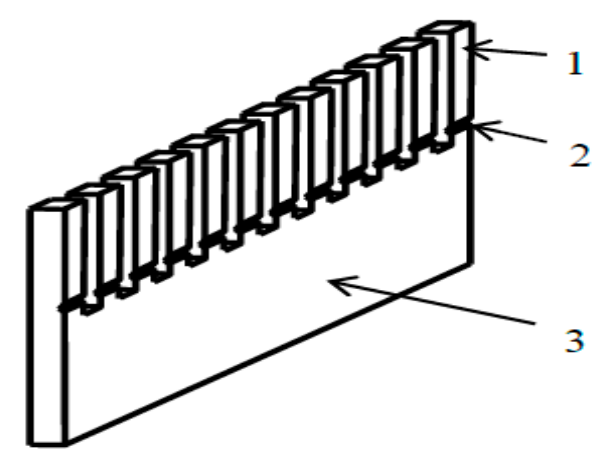

Fig. 5. Sample to determine the temperature ductile-brittle transition: 1 - specimen teeth; 2 - V-notches; 3 - specimen body

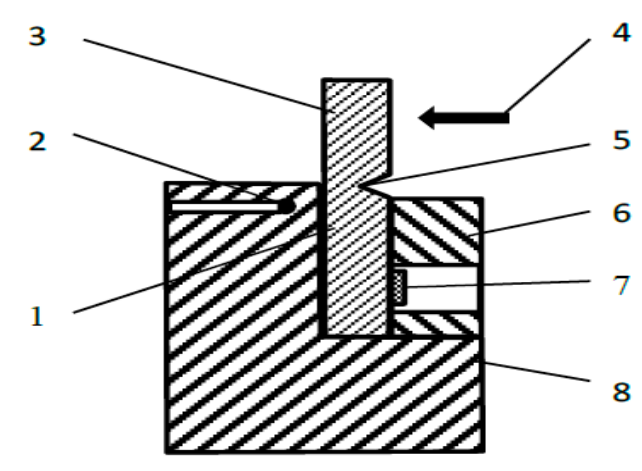

Fig. 6. Diagram of the sample attachment unit during the registration of $A E$ pulses: 1 - the sample body; 2 temperature sensor; 3 - specimen tooth; 4 -direction of impact; 5 - V-notches; 6 -grip; 7 - AE sensor; 8 - holder

The shape of the specimen is a plate with one side, which has a row of teeth. At the base of the teeth, V-notches are made parallel to the plane of the specimen. The direction of the incisions should correspond to the most likely direction of crack propagation in the control zone in case of possible destruction of the product. The force until complete destruction is applied to the free ends of the teeth in a monolithic specimen from the side of the V-notches. A full cycle of studies consists in testing the destruction of individual elements (teeth) of the specimen, which occurs with an increase in temperature.

The acoustic emission sensor is pressed tightly to the specimen during the whole test time, thus ensuring the stability of the readings when the teeth of the specimen are broken. In the case of brittle fracture, a powerful sound wave appears in the specimen, which creates a sequence of electrical pulses in the piezoelectric sensor acoustic emission. The temperature of a ductile-brittle transition is determined from the temperature dependences of the amplitude and activity of acoustic emission pulses, which correspond to brittle fracture when individual elements of a monolithic specimen are destroyed.

To destroy the elements of the specimen a designed impact machine, Fig. 7, this makes it possible to evaluate the fragile component by the impact test method. The tests of all the specimens were carried out with the recording of the load and time diagrams. Signals from the load cells of the impact machine, acoustic emission sensors and temperature are fed to the Handyscope HS multifunction meter, which is connected to the computer.

When determining the temperature of a ductile-brittle transition, the specimen is cooled beforehand to a temperature which is known to be significantly lower than the nominal for the given material $\sim-100{ }^{\circ} \mathrm{C}$. It is assumed that at such temperatures the element (tooth) of the sample collapses $\approx 100 \%$ brittle. During the impact test of the sample tooth, the temperature is gradually increased and simultaneously the acoustic emission signals are recorded. Based on the results of fractographic researches, the dependence of the intensity of acoustic emission signals and instrumented tests determine the temperature of the ductile-brittle transition particular of material. 


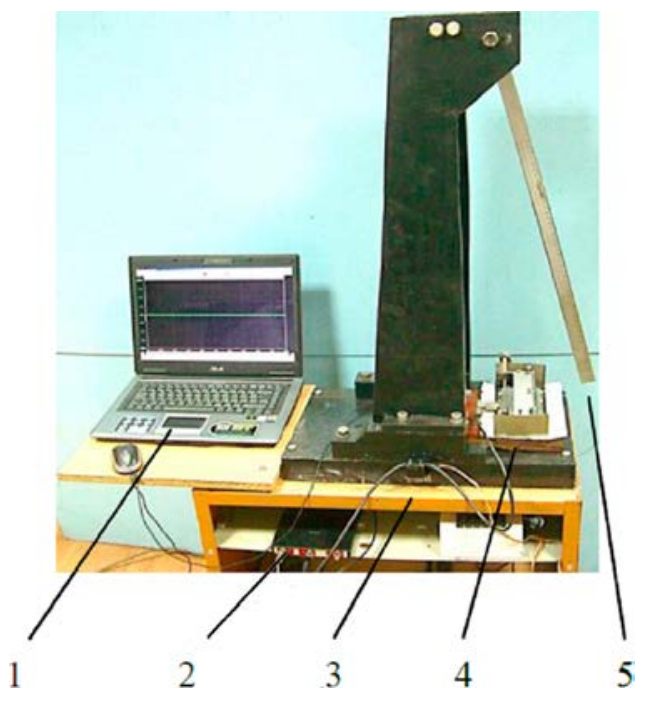

Specifications:

Impact energy up $4 \mathrm{~J}$ to $16 \mathrm{~J}$

Hammer Weight 0.6...1.5 kg

Angle of Deflection $90 \ldots 170^{\circ}$

Max. Hammer Speed $4.3 \mathrm{~m} / \mathrm{s}$

Temperature range from -150 to $20^{\circ} \mathrm{C}$

Number of teeth in the sample up to 20 pcs.

Cross-section of an element (tooth):

from $1 \times 1 \mathrm{~mm}$ to $4 \times 4 \mathrm{~mm}$

The maximum sampling rate of the sensors in the instrumented test mode is $100 \mathrm{MHz}$ for each channel Sensor acoustic emission (range of operation): from $80 \mathrm{kHz}$ to $300 \mathrm{kHz}$

Distance between the supports for testing Charpy subspecimens is selected individually

Fig. 7. Equipment for determining the DBTT based on the recording of AE signals (without a thermostat):

1- computer; 2 - Handyscope HS measuring instrument; 3 - signal amplifier AE; 4 - module for moving the sample; 5 - striker

This method allows you to take into account the difference in geometric dimensions when testing standard and sub-sized specimen. Correction factors are determined during the control experiments. The calibration of the equipment is based on the results of diagram fractures when examining the broken teeth of the sample, taking into account deviations in the dependence of the intensity of the acoustic emission signal on the fraction of brittle fracture. The introduction of specific parameters makes it possible to decompose the dependence of the number of pulses of brittle fracture, the sum of their amplitudes of individual elements on temperature. The results of these dependences determine the ductile-brittle transition of the material under study.

Method "Determination of the temperature of ductile-brittle transition in the test of subsized specimen of Charpy on impact test”. Materials for research were 16GNM steel, which was developed for use in of steam boiler drums and has rather high values for strength and has a high degree of plasticity [16]. The main purpose of this study was to determine the effect specimen size of Charpy from 16GNM steel on the results of the test on impact test. In particular, an emphasis was made to find the correlation parameter for determining the magnitude of the temperature of ductilebrittle transition of standard specimens by directly conducting trials of sub-sized specimens. In this case, it was possible to compare the data of the metal equipment after its long-term operation at elevated temperatures. The analysis of the temperature of ductile-brittle transition was carried out in two directions: the value of the absorbed energy and the percent of the ductile component on the surface of fracture.

To date, there have been many attempts to evaluate the properties of different steels when tested on stroke curve using a sub-size specimen. The main problems arising from the use of sub-size specimen are that the energy of the upper shelf and the temperature of ductile-brittle transition are significantly reduced than when testing standard specimen Charpy, Fig. 8 . In works $[17,18]$ it is shown that using the correlation parameters and taking into account the geometric dimensions of the specimen, it is possible to achieve a fairly good coincidence of values. In this case, the size effect results from a decrease in the

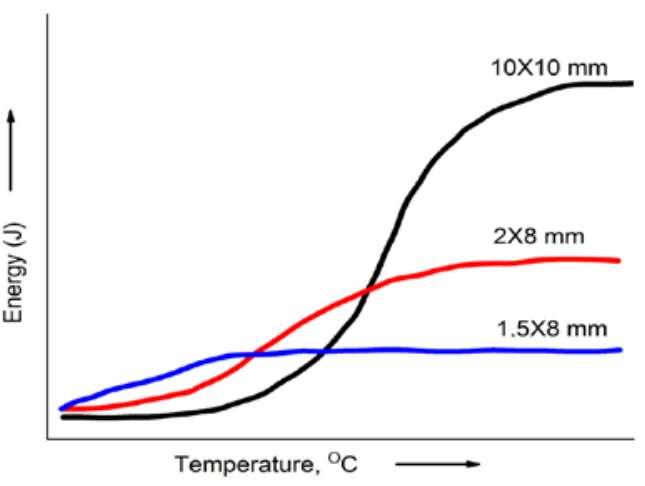

Fig. 8. Diagram of changes in the properties of material on the impact test of standard and sub-sized specimens 
volume of the specimen, which is associated with the viscous component of the fracture surface destroyed specimen.

In this work we used three group of the specimen's 16GNM steel. The size of the specimens Charpy for testing is shown in Table 2. All specimens were made in accordance with the requirements of GOST 9454-78 and ASTM E23-12c. Specimens were tested at a temperature from - 60 to $100{ }^{\circ} \mathrm{C}$. The analysis of the brittle component in the fracture was carried out in accordance with the requirements of GOST9454-78, ASTME23-12c and ISO148-1:2009. Using the microscope MMR-4 and specially designed software for these purposes, it was possible to investigate the surface of the fracture for quantification of the percent viscous component. In this case, optical measurements were compared with the data obtained in the instrumental tests.

When compiling this technique and comparing with literary data, the following studies were conducted:

- a comparative estimation of the temperature shift of the ductile-brittle transition;

- the validation of the stresses obtained with the instrumental tests, depending on the geometry of the specimen;

- an analysis was made between the values of the absorbed energy for different types of specimens;

- the connection between the temperature of the ductile-brittle transition and the energy of the upper shelf for different types of specimens is obtained;

- the dependence between the percent of the viscous component (which is measured optically) and the corresponding stresses during conducting of the instrumental tests is constructed.

Using the empirical formulas included in the ASTM, a quantitative estimate of the percent of brittle component in the Charpy specimens was performed. These formulas use the standard values for the instrumental tests: the beginning of the plastic deformation, the maximum stress, the beginning of brittle fracture, resistance to crack development. The instrumental tests of Charpy specimens at different temperatures allowed estimating the influence of specimen's sizes on the temperature shift of the ductile-brittle transition, to carry out a computer analysis of the values of the absorbed energy and to estimate the percent of the brittle component in the fracture.

The processing of the experimental data of the destruction operation was carried out using the approximating function of the hyperbolic tangent, according to PNAE:

$$
K C V=A+B \operatorname{th}\left(\frac{T-T_{0}}{C}\right),
$$

where $A=\frac{\mathrm{KCV}_{\text {max }}+\mathrm{KCV}_{\text {min }}}{2} ; B=\frac{\mathrm{KCV}_{\text {max }}-\mathrm{KCV}_{\min }}{2} ; T_{0}$ - temperature corresponding to value $A ; C-$ empirical constant.

Table 2

Charpy specimens size for testing

\begin{tabular}{c|c|c|c|c}
\hline Lot number & Specimen size, mm & Regulations & Operating time, $\mathrm{h}$ & $\begin{array}{c}\text { Number of } \\
\text { starts/stops }\end{array}$ \\
\hline 1 & $10 \times 10 \times 55$ & ГOCT 9454-78 & 0 & 0 \\
\hline 2 & $10 \times 10 \times 55$ & ГOCT 9454-78 & 282092 & 1830 \\
\hline 3 & $2 \times 8 \times 55$ & ГOCT 9454-78 & 282092 & 1830 \\
\hline 4 & $2 \times 8 \times 55$ & ГOCT 9454-78 & 317243 & 1620 \\
\hline 5 & $2.5 \times 10 \times 55$ & ASTM E23 & 282092 & 1830 \\
\hline 6 & $1.5 \times 8 \times 55$ & ГOCT 9454-78 & 282092 & 1830 \\
\hline
\end{tabular}

The graphs obtained from the above equation (3) are the source information for determining the critical brittleness temperature. According to the results of the research, the final dependencies the temperature of the ductile-brittle transition for 16GNM steels after long-term operation were constructed, Figs. 9 and 10 and conclusions were made on the state the metal of steam boilers drums. According to the results of the treatment of the dependence of the impact toughness, dependence between 
the critical brittleness temperature and the value of the impact toughness at room temperature was obtained. In the method developed in NSC KIPT for a steel 16GNM linear dependence is used:

$$
T_{K}=110-1.7 \cdot\left(\mathrm{KCV}_{20}\right) \text {, }
$$

where $\mathrm{KCV}_{20}$ - the value of impact toughness at a test temperature of $20^{\circ} \mathrm{C}$. In work [19], a fairly stable relationship between the critical brittleness temperature and the value of impact toughness at room temperature is shown. This dependence has the form:

$$
T_{K}=-40.546 \cdot \ln \left(\mathrm{KCV}_{20}\right)+177.9 \text {, }
$$

where $\mathrm{KCV}_{20}$ - the value of impact toughness at a test temperature of $20^{\circ} \mathrm{C}$. These expressions can be used in the first approximation in determining the critical brittleness temperature without conducting serial tests and in assessing the residual life of the equipment. Based on the results of these studies, Table 3 was constructed, which analyzes various pitches to determine the critical brittleness temperature.

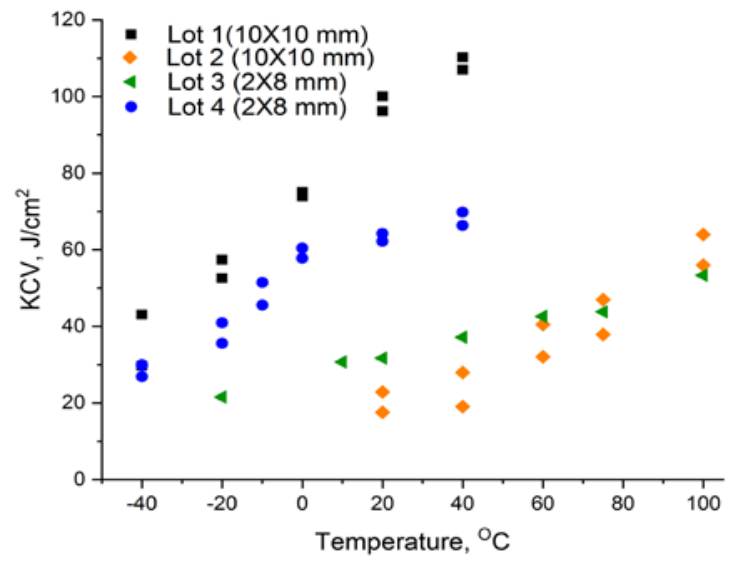

Fig. 9. Temperature dependence of the impact toughness for 16GNM steel

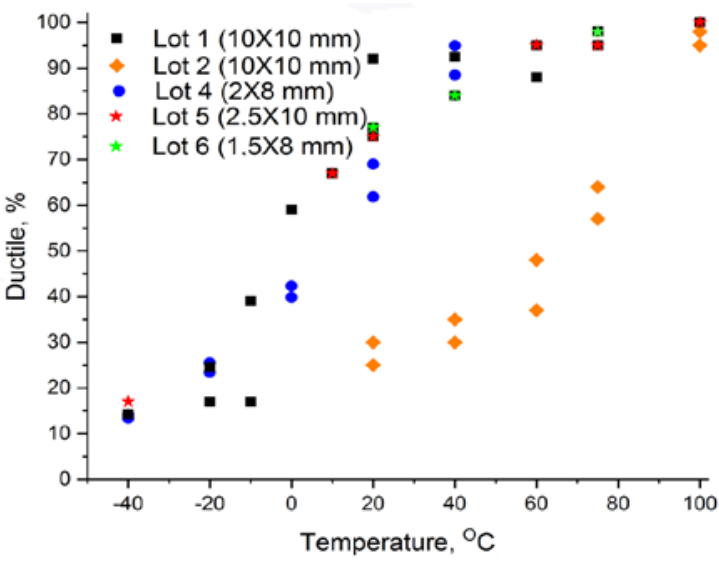

Fig. 10. Final dependence of the ductile component from the test temperature, 16GNM steel

Table 3

Determination the critical temperature brittleness in different approaches

\begin{tabular}{c|c|c|c|c|c}
\hline $\begin{array}{c}\text { Specimen, } \\
\mathrm{mm}\end{array}$ & $\begin{array}{c}\text { Operating time, } \\
\mathrm{h}\end{array}$ & $\begin{array}{c}\text { PNAE } T_{K}, \\
{ }^{\circ} \mathrm{C}\end{array}$ & $\begin{array}{c}\text { ISO-148 } T_{K}, \\
{ }^{\circ} \mathrm{C}\end{array}$ & $\begin{array}{c}\text { BTI } T_{K}, \\
{ }^{\circ} \mathrm{C}\end{array}$ & $\begin{array}{c}\text { NSC KIPT } T_{K}, \\
{ }^{\circ} \mathrm{C}\end{array}$ \\
\hline $10 \times 10$ & origin & -23 & 0 & -5 & -30 \\
\hline $10 \times 10$ & 282092 & 65 & 70 & 51 & 73 \\
\hline $2 \times 8$ & 282092 & 10 & 15 & 48 & 69 \\
\hline $2 \times 8$ & 317243 & -20 & -20 & -9 & 0 \\
\hline
\end{tabular}

Conclusions according to the method. The value of the temperature of the ductile-brittle transition of standard specimens can be directly obtained by conducting studies of the temperature of the ductile-brittle transition of sub-sized specimens having corresponded to the V-notching.

The relative difference between the values in trials of sub-sized specimens is small and wellcoordinated within the experimental error. The nature of the surfaces fracture of sub-sized specimens is practically the same as in standard specimens. The normalization of the magnitude of the energy of the upper shelf led to almost identical values for standard and sub-sized specimens coincided with an error of less than $\pm 15 \%$, thus the effect associated with the specimens size may disappear. The geometry of the notching for sub-sized specimens can lead to a significant shift in the ductile-brittle transition temperature to $\approx 20^{\circ} \mathrm{C}$.

As a result of tests at $-40^{\circ} \mathrm{C}$, a number of specimens with a thickness of $1.5 \mathrm{~mm}$ showed a significant fraction of the plastic component of $\approx 15 \%$, which led to higher values of the critical brittleness 
temperature than in standard specimens. This suggests that a large proportion of the volume of a subsized specimen experiences plastic deformation at impact toughness tests on even at very low temperatures. Thus, it is not possible to associate proportionally the data with the predicted change in the values ductile-brittle transition temperature with a decrease in the specimen size. Consequently, for a steel 16GNM, in transition from the standard method of determining the critical brittleness temperature on PNAE, to the test method of sub-sized specimens, it is necessary to consider the shift of critical brittleness temperature by approximately $\sim 60^{\circ} \mathrm{C}$, depending on the specimen size and the notching in the specimen.

Conclusions. Equipment was developed to determine the temperature of ductile-brittle transition of sub-scale specimens based on the results of instrumental tests, registration of acoustic emission signals and fractographic researches. Signal registration acoustic emission is an effective method in determining of the type of specimen destruction. The amplitude and temporal parameters pulses of acoustic emission that are registered at brittle and ductile destruction of specimens vary significantly. A specimen was developed for the determination of the ductile-brittle transition temperature as a result of the registration of acoustic emission signals. Specimen for research can be made from a template cutout from the surface of equipment that is in use. This technique is adapted to carry out trials of subspecimens Charpy. The analysis carried out may be of interest to supervisors and regulators in terms of safe operation of equipment.

\section{Література}

1. Ерак Д.Ю., Журко Д.А., Папина В.Б. Интерпретация результатов ускоренного облучения материалов корпусов реакторов ВВЭР-1000. Проблемы прочности. 2013. № 4. С. 51-63.

2. Чернобаева А.А., Платонов П.А. Особенности радиационного охрупчивания материалов корпусов реакторов в различных диапазонах флюенсов. ВАНТ, Серия Материаловедение и новые материаль. 2009. Вып. 1(73). С. 206-219.

3. Марголин Б.3., Юрченко Е.В., Морозов А.М., Пирогова Н.Е. Анализ связи между механизмами радиационного охрупчивания и влиянием флакса нейтронов применительно к материалам корпусов реакторов ВВЭР. Проблемь прочности. 2013. № 4. С. 27-50.

4. Руденко А.Г., Шиляев Б.А., Воеводин В.Н., Ожигов Л.С. Эволюция радиационного повреждения материалов конструкций реактора ВВЭР-1000. ВАНТ. 2008. № 2. С. 78-82

5. Evolution of the nanostructure of VVER-1000 RPV materials under neutron irradiation and post irradiation annealing / M.K. Miller, A.A. Chernobaeva, Y.I. Shtrombakh, K.F. Russell, R.K. Nanstad, D.Y. Erak, O.O. Zabusov. J. Nucl. Mat. 2009. 385. C. 615-620.

6. Связь служебных характеристик сталей корпусов ядерных реакторов с эволюцией их наноструктуры под действием рабочих температур и облучения / Б.А. Гурович, Е.А. Кулешова, Д.А. Мальцев, С.В. Федотова, А.С. Фролов. ВАНТ. 2013. № 2(84). С.3-10.

7. Ерак Д.Ю., Папина В.Б., Чернобаева А.А. Эффекты температурного старения в материалах сварных швов ВВЭР-1000. Материаль научн.-техн. конф. молодых специалистов 16 НПКб, 26-27 марта 2014 г. ОКБ ГИДРОПРЕСС.

8. Юханов В.А., Шур А.Д. Исследование термического старения корпусных сталей для атомных энергетических установок с целью обоснования ресурса оборудования на срок до 60 лет. $M u$ TOM. 2006. №7(613). С. 23-27.

9. Гурович Б.А., Ерак Д.Ю., Журко Д.А., Кулешова Е.А., Чернобаева А.А. и др. Прогнозирование радиационного охрупчивания материалов корпусов ректоров ВВЭР-1000 при продлении срока службы. 9 МНТК Обеспечение безопасности АЭС с ВВЭР. Материалы научн.-техн. конф. 19-22 мая 2015 г. ОКБ ГИДРОПРЕСС. 2015.

10. Fukuya K. Current understanding of radiation-induced degradation in light water reactor structural materials. Journal of Nuclear Science and Technology. 2013. Vol. 50, № 3, P. 213-254.

11. Accurate Determination and Benchmarking of Radiation Field Parameters, relevant for Pressure Vessel Monitoring (REDOS). Final Report EUR 21771 EN 200563 p.

12. Пугач А.М., Демехин В.Л., Буканов В.Н., Пугач С.М. Функционалы нейтронного потока воздействующего на корпус реактора ВВЭР-440. Ядерна та радіаційна безпека. 2008. № 2. С. $28-31$. 
13. Голованов В.Н., Раецкий В.М. Эксперимент по уточнению кинетики радиационного охрупчивания металла на толщине корпуса реакторов ВВСР-1000 и ВВСР-1500 для уточнения степени консерватизма проектных решений. Материалы научн.-техн. конф. 23-25 мая 2005 г., ОКБ ГИДРОПРЕСС. 2005.

14. Пластина металла JRQ как модель стенки корпуса реактора / М. Брумовский, В.Н. Голованов, В.М. Раецкий, М. Китка, Д.В. Козлов, Г.В. Шевляков. ВАНТ. 2007. № 2 .С. 113-118.

15. Спосіб визначення критичної температури в'язко-крихкого переходу: пат. 97283, Україна: МПК14 G01N29/06, G01N29/14. № 21409040; заявл. 11.08.2014; опубл. 10.03.2015, Бюл. № 5. 4 с.

16. Ожигов Л.С., Митрофанов А.С., Толстолуцкая Г.Д. и др. Комплексные исследования металла барабанов котлов тепловых электростанций. Теплоэнергетика. 2017. № 5. С. 40-47.

17. Alexander D.J., Klueh R.L. "Specimen Size Effects in Charpy Impact Testing” in Charpy Impact Test: Factors and Variables, ASTM STP 1072. J.M. Holt, Eds. American Society for Testing and Materials. Philadelphia. 1990.

18. Schubert L.E., Kumar A.S., Rosinski S.T., Hamilton M.L. Effect of Specimen Size on the Impact Properties of Neutron Irradiated A533B Steel. J. Nucl. Mat. 1995. 225. C. 231-237.

19. Гринь Е.А., Анохов А.Е., Зеленский А.В., Федина И.В. Исследование металла барабанов паровых котлов из стали 16ГНМ после длительной эксплуатации. Теплоэнергетика. 2010. №. 6 С. 37-42.

\section{References}

1. Erak, D.Yu., Zhurko, D.A., \& Papina, V.B. (2013). Interpretation of Accelerated Irradiation Results for Materials of WWER-1000 Reactor Pressure Vessels. Strength of Materials, 4, 51-63.

2. Chernobaeva, A.A., \& Platonov, P.A. (2009). Features of radiation embrittlement of reactor vessel materials in various ranges of fluences. PAST, 1(73), 206-219.

3. Margolin, B.Z., Yurchenko, E.V., Morozov, A M., \& Pirogova, N. E. (2013). Analysis of relationship between the radiation embrittlement mechanisms and the influence of neutron flux in respect of WWER reactor pressure vessel materials. Strength of Materials, 4, 27-50

4. Rudenko, A.G., Shilyaev, B.A., Voyevodin, V.N., \& Ozhigov, L. S. (2008). Evolution of the radiation damage materials of the reactor VVER-1000. PAST, 2, 78-82.

5. Miller, M.K., Chernobaeva, A.A., Shtrombakh, Y.I., Russell, K.F., Nanstad, R.K., Erak, D.Y., \& Zabusov, O.O. (2009). Evolution of the nanostructure of VVER-1000 RPV materials under neutron irradiation and post irradiation annealing. J. Nucl. Mat., 385, 615-620.

6. Gurovich, B.A., Kuleshova, E.A., Maltsev, D.A., Fedotova, S.V., \& Frolov, A.S. (2013). Relationship of operational characteristics of steels for pressure vessels of nuclear reactors with evolution of its nanostructure in conditions of operation temperatures and irradiation. PAST, 2(84), 3-10.

7. Erak, D.Yu., Papina, V.B., \& Chernobaeva, A.A. (2014). Effects of temperature aging in weld materials of WWER-1000. 16 STK, OKB Gidropress.

8. Yukhanov, V.A., \& Scur, A.D. (2006). Investigation of thermal aging vessel steels for nuclear power plants in order to support hardware long-term for up to 60 years, Metal Science and Heat Treatment 7 (613), 23-27.

9. Gurovich, B.A., Erak, D.Yu., Zhurko, D.A., \& Kuleshova, E.A. et al. (2015). Prediction of radiation embrittlement for VVER-1000 pressure vessel materials on service lifetime extension, 9 ISTC "Safety assurance of NPP with VVER", OKB Gidropress.

10. Fukuya, K. (2013). Current understanding of radiation-induced degradation in light water reactor structural materials. Journal of Nuclear Science and Technology, 50, 3, 213-254.

11. Accurate Determination and Benchmarking of Radiation Field Parameters, relevant for Pressure Vessel Monitoring (REDOS). (2005). Final Report EUR 21771 EN. 63.

12. Pugach, A.M., Demekhhin, V.L., Bukanov, V.N., \& Pugach, S.M. (2008). Neutron flux functionals affecting VVER-440 reactor pressure vessel. Nuclear \& Radiation safety, 2, 28-31.

13. Golovanov, V.N., \& Raetsky, V.M. (2005). Experimental validation of the radiation kinetics of metal embrittlement over the thickness of the VVER-1000 and VVER-1500 reactor vessels to specify the conservatism degree of the project solutions. ISTC-2005, OKB Gidropress.

14. Brumovsky, M., Golovanov, V.N., Raetsky, V.M., Kytka, M., Kozlov, D.V., \& Shevlyakov, G.V. (2007) JRQ steel plate as a reactor vessel wall dummy. PAST, 2, 113-118.

15. Ozhigov, L.S., Rudenko, O.G., \& Gozhenko, S.V. (2015). Method for determining the critical temperature of ductile-brittle transition. Ukraine Patent No. 97283. 
16. Ozhigov, L.S., Mitrofanov, A.S., \& Tolstolutskaya, G.D. et al. (2017). Comprehensive investigation of the metal in drums of boilers at thermal power stations. Thermal Engineering, 5, 40-47.

17. A1exander, D.J. \& Klueh, R.L. (1990). "Specimen Size Effects in Charpy Impact Testing” in Charpy lmpact Test: Factors and Variables, ASTM STP 1072, J. M. Holt, Ed., American Society for Testing and Materials, Philadelphia.

18. Schubert, L.E., Kumar, A.S., Rosinski, S.T., \& Hamilton, M.L. (1995). Effect of Specimen Size on the Impact Properties of Neutron Irradiated A533B Steel. J. Nucl. Mat., 225, 231-237.

19. Grin', E.A., Anokhov, A.E., Zelenskii, A.V. \& Fedina, I. V. (2010). Studying the metal of steam boiler drums made of grade 16GNM steel after its long-term operation. Thermal Engineering, 57, 6, 37-42.

Руденко Олексій Геннадійович; Rudenko Oleksii, ORCID: https://orcid.org/0000-0002-4389-6252

Восводін Віктор Миколайович; Voyevodin Victor, ORCID: https://orcid.org/0000-0003-2290-5313

Гоженко Сергій Васильович; Gozhenko Sergiy, ORCID: https://orcid.org/0000-0001-6190-1134

Міщенко Павло Олександрович; Mishchenko Pavel, ORCID: https://orcid.org/0000-0001-6035-4968

Received February 15, 2019

Accepted April 24, 2019 